\title{
Article \\ Comprehensive Flood Risk Assessment for Wastewater Treatment Plants under Extreme Storm Events: A Case Study for New York City, United States
}

\author{
Qing Sun ${ }^{1}\left(\mathbb{D}\right.$, Rouzbeh Nazari ${ }^{1,2, *}$, Maryam Karimi ${ }^{1,2}\left(\mathbb{D}\right.$, MD Golam Rabbani Fahad ${ }^{1}\left(\mathbb{D}\right.$ and Robert W. Peters ${ }^{1}(\mathbb{D}$ \\ 1 Department of Civil, Construction and Environmental Engineering, \\ The University of Alabama at Birmingham, Hoehn Engineering Building, 1075 13th Street South, \\ Birmingham, AL 35294-4440, USA; sqing01@uab.edu (Q.S.); karimi@uab.edu (M.K.); \\ fahadr@uab.edu (M.G.R.F.); rwpeters@uab.edu (R.W.P.) \\ 2 Department of Environmental Health Science, School of Public Health, Ryals Public Health Building (RPHB), \\ The University of Alabama at Birmingham, 1665 University Boulevard, Birmingham, AL 35294-0022, USA \\ * Correspondence: rnazari@uab.edu
}

check for updates

Citation: Sun, Q.; Nazari, R.; Karimi, M.; Rabbani Fahad, M.G.; Peters, R.W. Comprehensive Flood Risk

Assessment for Wastewater Treatment Plants under Extreme Storm Events: A Case Study for New York City, United States. Appl. Sci. 2021, 11, 6694. https://doi.org/ 10.3390/app11156694

Academic Editor: Francesco Fiorillo

Received: 26 May 2021

Accepted: 14 July 2021

Published: 21 July 2021

Publisher's Note: MDPI stays neutral with regard to jurisdictional claims in published maps and institutional affiliations.

Copyright: (c) 2021 by the authors. Licensee MDPI, Basel, Switzerland. This article is an open access article distributed under the terms and conditions of the Creative Commons Attribution (CC BY) license (https:// creativecommons.org/licenses/by/ $4.0 /)$.
Featured Application: This research was designed to understand the effects of fine scale subbasin generation technique to assess the risk of flooding for wastewater treatment plants in New York City. The article identifies the total risk of flooding from multiple sources including extreme weather events, climate change, and high intensity rainfall.

Abstract: Wastewater treatment plants (WWTPs) in the City of New York, United States, are particularly vulnerable to frequent extreme weather events, including storm surges, high-intensity rainfall, and sea level rise, and are also affected by the cascade of these events. The complex structural configuration of WWTPs requires very fine-scale flood risk assessment, which current research has not pursued. We propose a robust technique to quantify the risk of inundations for the fourteen WWPTs through an automated sub-basin creation tool; 889 sub-basins were generated and merged with high-resolution building footprint data to create a comprehensive database for flood inundation analysis. The inundation depths and extents for the WWTPs and flood-prone regions were identified from hydrodynamic modeling of storm surge and sea level rise. The economic damage due to flooding for the WWTPs was also quantified using the HAZUS-MH model. Results indicated that the storm surges from various categories of hurricanes have the dominant impacts on flood depths around WWTPs, followed by high-intensity rainfall. Sea level rise was shown to have a relatively minor impact on flood depths. Results from economic damage analysis showed that the WWTPs are subjected to damage ranging from USD 60,000 to 720,000, depending on the size of the WWTP and the extremity of storm surge. The method of analyzing the inundation status of the research object through the sub-basin enables more accurate data to be obtained when calculating the runoff. It allows for a clearer view of the inundation status of the WWTPs when combined with the actual buildings. Using this database, predicting flood conditions of any extreme event or a cascade of extreme events can be conducted quickly and accurately.

Keywords: wastewater treatment plant; storm surge; high-intensity rainfall; sea level rise; sub-basins; SLOSH; runoff model; NOAA; HAZUS-MH

\section{Introduction}

The world is experiencing rapid urbanization. Today, 55\% of the global population lives in urban areas [1]. It is estimated that by 2050, the proportion of the people living in cities in the world's total population will increase to $68 \%$ (about 6 billion) [1]. Urbanization will not only reduce the area of arable land but will also increase the greenhouse conditions and heat island effects [2-5]. Hence, in the process of rapid urbanization, the threat of 
extreme weather changes has become increasingly prominent. Extreme events such as sea level rise, high-intensity rainfall, and storm surge have become major problems that cities must face [6-9]. New York City (NYC) is the most populous coastal city in the United States. It has extensive beaches, ports, rivers, and wetlands. It is extremely vulnerable to catastrophic flooding because it has 520 miles of coastline [10]. Because of its vast coastal terrain, NYC is extremely vulnerable to various extreme climates such as storm surges, high-intensity rainfall, and sea level rise. With climate change and rising sea levels brought about by urbanization, these risks will increase in the forecast. There are 14 WWTPs in NYC [11], which treat 1.3 billion gallons of wastewater produced by 8.336 million people daily [11]. Meanwhile, the WWTPs in Los Angeles, the second-most populous city in the United States, can treat 400 million gallons of wastewater produced by 4.0 million people every day [12]. That means the WWTPs in NYC can treat 156 gallons per person per day, while those in Los Angeles can just treat 100 gallons per person per day. The WWTPs in NYC have a greater workload. If a WWTP becomes flooded, many people will lose wastewater treatment services. Therefore, it is imperative to accurately predict and evaluate the damage caused by storm surges, high-intensity rainfall, and sea level rise. Previous studies on the impact of floods on WWTPs focused primarily on the WWTP being regarded as a point on the map. However, the WWTP is composed of many facilities. If WWTPs are considered as a point on the map, it is impossible to fully understand the actual flooding situation of the WWTP.

This study aims to investigate the WWTPs in NYC as the study object, using GIS to analyze the inundation of the WWTP buildings suffered by storm surges, sea level rise, and high-intensity rainfall, and evaluate the impact of various extreme weather situations on the WWTPs. To achieve this goal, we propose a systematic sub-basin creation algorithm based on high-resolution land cover and building footprint data that reflects the microscale flood variation for the WWTPs. In addition, this study also uses the damage assessment formula used by HAZUS-MH [13] to estimate the amount of damage under different flooding conditions. The compounded effect of flooding from sea level rise, storm surge, high intensity rainfall and riverine flooding were analyzed using the concept of total water level.

\section{Literature Review}

NYC lies on the edge of the Atlantic Ocean. As one of the largest cities in the world, it has a significant influence on the global economy, business, finance, media, politics, education, and entertainment. NYC's 2017 GDP was identified as USD 937 billion [14]. As an economic and cultural center, it has the largest urban population in the United States. Before 1 July 2019, according to the U.S. Census Bureau statistics, this city had an area of 1214.4 square kilometers with a population of approximately 8.336 million people living on $789 \mathrm{~km}^{2}$ of land [15].However, the wastewater treatment system built by NYC decades ago may not be able to cope adequately with the increasing variability and extreme tidal flooding and storm surges that are expected to affect the system [16]. Most WWTPs in NYC were designed to be located at low altitudes along the coast to use gravity to transport wastewater and reduce the use of pumps, thereby saving the cost of wastewater discharge and transportation. However, it also places the WWTPs at a lower elevation and increases the risk of the plant being flooded. The sea level on the coast of New York is 9 inches higher than in 1950 [17-19]. Forecasts based on the global climate models (GCMs) show that sea levels will rise by 7 to 12 inches by the 2050s and 12 to 23 inches ( 30.48 to $58.42 \mathrm{~cm}$ ) by the 2080s [18]. Because these WWTPs are in the coastal area of NYC, they are more susceptible to sea level rise. Strom surges are another concern for wastewater plants and are mainly caused by strong winds in hurricanes or tropical storms [20-22]. The frequency of hurricanes is accelerating, and the losses caused by them are becoming ever more severe. Hurricane Sandy hit NYC in 2012. Subways, highways, and parking lots were flooded, houses and industries were destroyed, 53 people died, and approximately USD 19 billion in economic losses were caused by Hurricane Sandy $[6,23]$. 
Hurricane Sandy brought high winds and a record $4.27 \mathrm{~m}$ (14 ft) storm surge to NYC [24]. Many WWTPs and pumping stations located near the water in the city were flooded or damaged. Hurricanes bring not only storm surges but also high-intensity rainfall. When high-intensity rainfall or continuous rainfall exceeds the city's drainage capacity, water accumulation occurs in the city. The way to reduce accumulated water is to allow the water to percolate through the soil. However, urbanization has reduced surface vegetation, ponds, and lakes, increased impervious surfaces, and reduced soil permeability. Cities are full of impervious surfaces, including streets, roofs, and parking lots, that generate large amounts of stormwater runoff [25]. The impervious surface covers approximately $72 \%$ of NYC's land area [26]. Because of the large area of impervious surface, if NYC encounters high-intensity rainfall, flooding likely occurs. If storm surges and high-intensity precipitation occur simultaneously in low-lying coastal areas, the possibility of flooding is greater [27]. Therefore, the damage caused by cascading events also needs to be considered. For example, the study conducted by Karamouz et al. assessed the reliability of NYC WWTPs during flooding by proposing a probabilistic framework [28]. A study conducted by Hamidi et al. focused on the uncertainty analysis of urban sewer system of NYC from the perspective of combined sewer overflow (CSO), but the associated impact on WWTPs during flooding has not been analyzed [26]. De Sousa et al. proposed a life cycle assessment framework to evaluate the impact of green infrastructure technologies for the Hunts Point WWTP in NYC [29]. After Hurricane Sandy, comprehensive wastewater resiliency plans were created by Balci and Cohn, but the quantification of flood damage for the 14 WWTPs in NYC were not performed from a microscale perspective [30]. Prioritizing investments in improving flood resilience and reliability of WWTP infrastructure was also assessed by Karamouz et al. through a multicriteria decision-making process for the fourteen WWTPs in NYC [31].

\section{Data and Methodology}

\subsection{Creating a Sub-Basin Database}

This study uses GIS and NYC's digital elevation model (DEM) (1 m resolution) to create 889 sub-basins for NYC. The study conducted by Al-Suhili et al. showed that increasing the number of sub-basins in an urbanized area can improve the accuracy of flood inundation [32]. This study also adopted this method and completed the division of sub-basins through GIS. The procedure involves using the flow direction and basin tools to create a grid depicting all basins in NYC. Reclassification and merge tools were then used to merge all basins less than ten thousand square meters with other basins. For a sub-basin with an area exceeding ten million square meters, this study divided the basin into several sub-basins depending on the land cover and roads to make its area smaller. For this analysis, the sub-basins were identified based on their land cover characteristics. Generally, for rainfall-runoff analysis the study area needs to be divided into several hydrological basins that contribute to the surface runoff during rainfall events. Due to the limitation in data resolution and computational capacity, the basins are quite often aggregated into a large watershed that does not reflect the microscale variation surrounding complex structures such as WWTPs. Therefore, it was necessary to use a high-resolution land use and building footprint dataset to clearly subdivide individual basins into smaller sub-basins that represents proper surface runoff characteristics for flood damage analysis.

When the area of a particular sub-basin is too large, the sub-basin can be divided into smaller parts according to the road. In addition, it can also be divided according to the land cover of the sub-basin. For example, when dividing the Manhattan area into sub-basins, after basin analysis, several sub-basins with very large areas appeared in the center of Manhattan. It was found that Central Park is in it, and Central Park is almost entirely covered by green space, so Central Park was separated into one sub-basin. Figure 1 shows the whole process of database processing using GIS. In the end, NYC was divided into 889 sub-basins. The final map of the 889 sub-basins in NYC is shown in Figure 2. There are 131 sub-basins in Manhattan, 234 sub-basins in Brooklyn, 184 sub-basins in the Bronx, 
207 sub-basins in Queens, and 133 sub-basins in Staten Island. Based on the sub-basins, the SLOSH model, the runoff model, and the shapefile of flood depth at different heights of sea level rise provided by NOAA were used to build the database. We utilized the highresolution ( $3 \mathrm{ft}$ ) land cover dataset which is subclassified into seven different categories: tree canopy, grass/shrub, bare earth, water, buildings, roads, and other paved surfaces. The dataset has an overall accuracy of $96 \%$ for NYC. The land cover database was also merged with the fine-scale building footprint data to create high-resolution sub-basins for the WWTPs. We used the land cover database to subdivide the study area into smaller subbasins, as described in Figure 1. Associated curve number values and surface roughness characteristics were also assumed based on the land use/land cover dataset. The level of damage for different land cover types varies substantially based on the surface roughness criteria. The urban land cover types were classified as most susceptible to flooding due to a low friction factor and greater surface runoff during rainfall events.

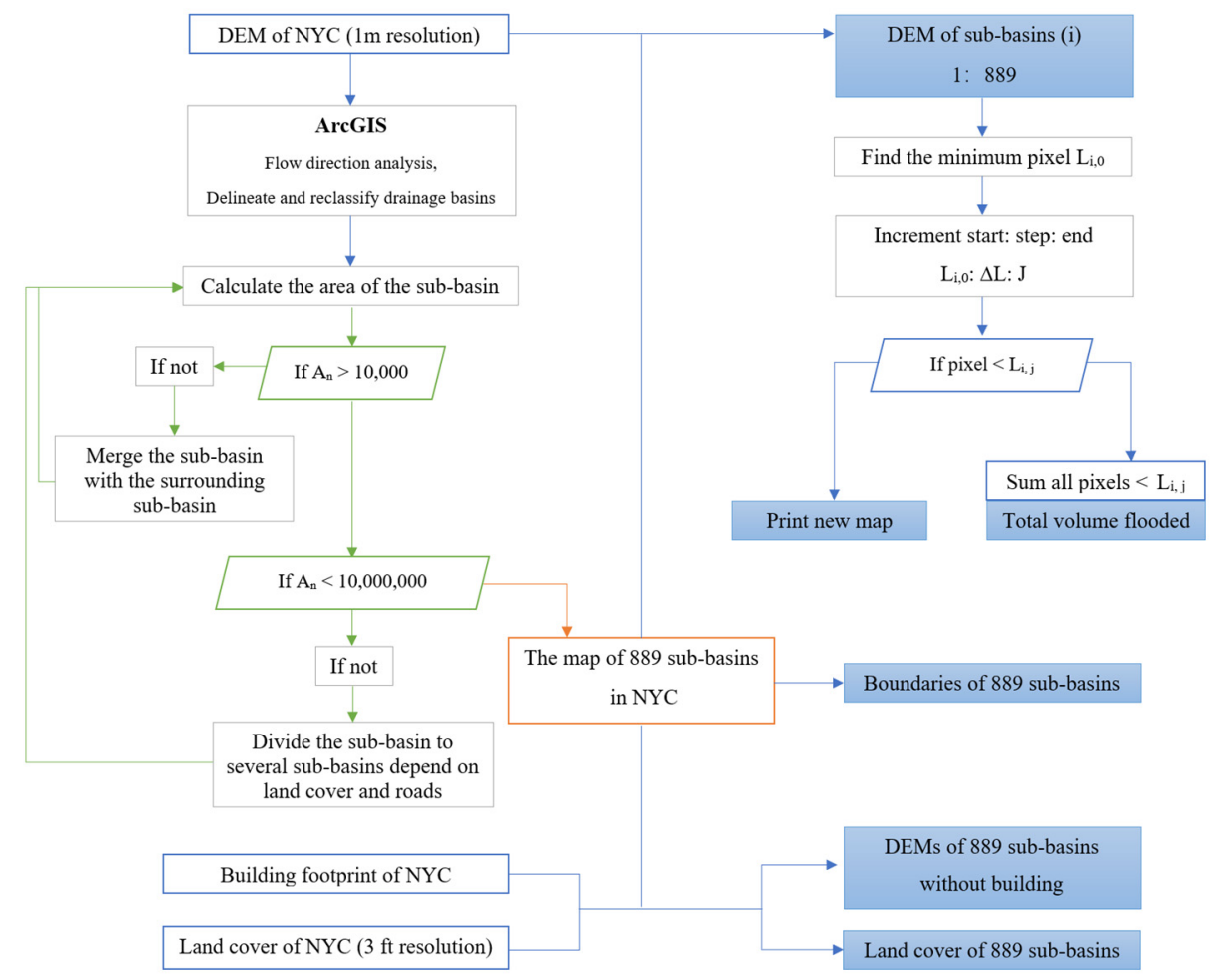

Figure 1. The process of dividing NYC into 889 sub-basins and database processing.

Additionally, the $3 \mathrm{ft}(0.91 \mathrm{~m})$ resolution raster image of NYC and the shapefile of footprint outlines of buildings in NYC are also parts of the database preparation. From these two files, digital elevation (DEM) files of sub-basins without buildings can be created. For the DEMs of sub-basins without buildings, starting from the lowest elevation of each sub-basin $L_{0}$, with an interval $\Delta L$ of $0.1 \mathrm{~m}, L_{0}+j \cdot \Delta L$, is regarded as the flood level $L_{j}$. The formula for calculating the flood volume for each flood level is given in Equation (1).

$$
V_{i, j}=\sum_{m=1}^{N_{i}}\left(L_{i, j}-P l_{m}\right) * A p_{m}
$$

where $N_{i}$ represents the number of pixel levels smaller than the flood level in sub-basin $i, P l_{m}$ is the pixel level less than the flood level, and $A p_{m}$ is the corresponding pixel area. The database includes the information of the boundary maps of 889 sub-basins and the associated topographic elevations, areas of three different land cover classes (bare soil, tree canopy, and grass) in 889 sub-basins without buildings, shapefiles of footprint outlines of buildings of 14 WWTPs in NYC, and the table of flood volume for each flood level in the 
889 sub-basins. The flood volume data were later converted to flood inundation maps using the "bathtub" approach. To achieve that we utilized the DEM at $3 \mathrm{ft}(0.91 \mathrm{~m})$ resolution and used the maximum flood level $\left(L_{j}\right)$ by selecting all areas that are below the specified new water level height. Although the bathtub model might overpredict flood extent compared to hydraulic and hydrodynamic modeling approaches for microlevel analysis, it provides a simple approach and provides savings in input data and computation requirements [33].

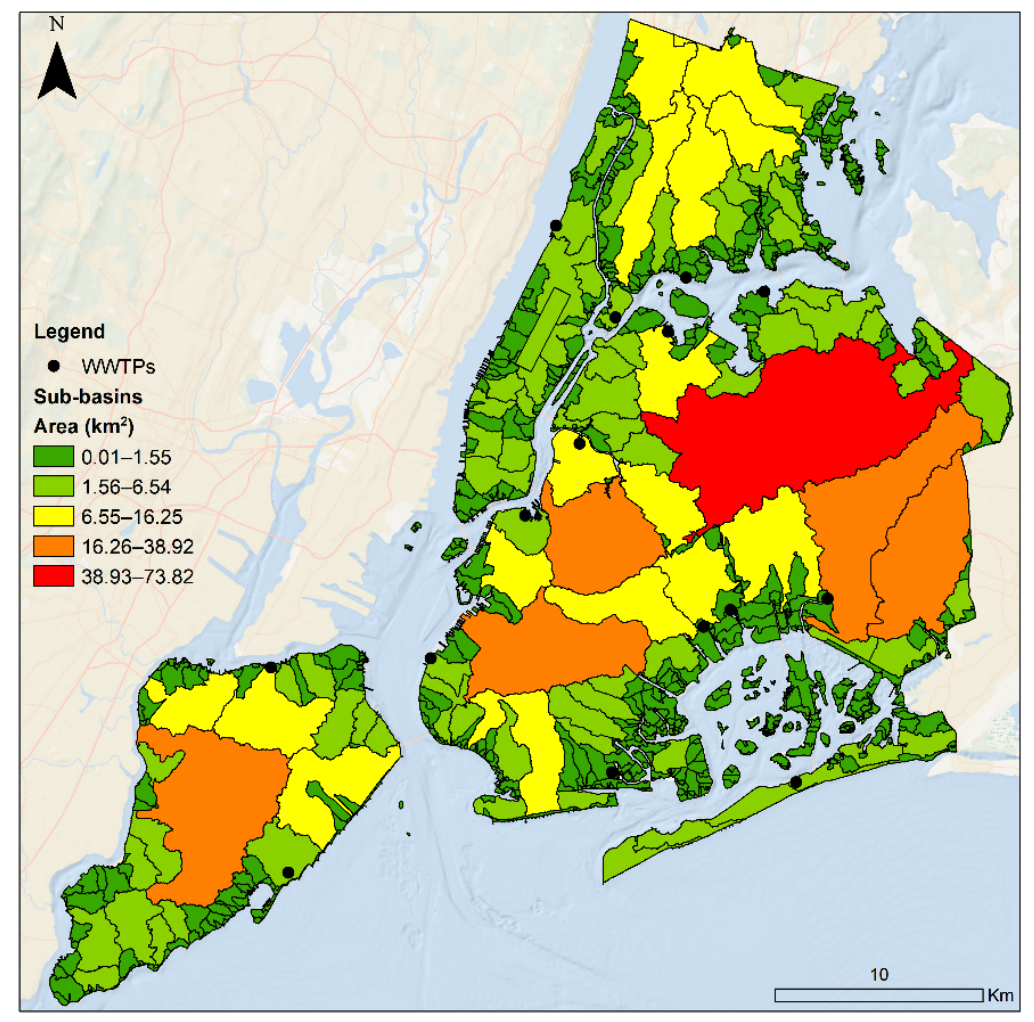

Figure 2. The map of 889 sub-basins in NYC.

\subsection{Storm Surge Analysis}

The Sea, Lake, and Overland Surges from Hurricanes (SLOSH) model is a twodimensional operational storm surge model developed by the National Weather Service [34]. The SLOSH model uses pressure, size, forward speed, and tracking data to calculate the storm surge height of a tropical cyclone to create a wind field model that pushes water around [34]. The composite approach within the SLOSH uses hypothetical hurricanes to run thousands of synthetic hurricane scenarios [34]. This method produces two products, including the maximum envelope of water (MEOWs) and the maximum of MEOWs (MOMs). The MEOW product is the maximum height of the storm surge reached at each point in the model domain when thousands of synthetic storms with the same storm parameters but different parallel paths are modeled [35]. The MOM product is the maximum storm surge height obtained after merging all MEOW surge results from Saffir-Simpson storms of the same category [35]. In this study, the inundation maps of hurricane categories 1 and 2 were created for 889 sub-basins in NYC through GIS.

\subsection{High-Intensity Rainfall-Runoff Model}

This study divides each rainfall event into $n$ time intervals, and each time interval is the same time $\Delta T$. Equation (2) for calculating the time interval follows:

$$
n=T / \Delta T
$$


where $n$ is the number of time intervals in the rainfall period, $T$ is the total duration of the rainfall period, and $\Delta T$ is the duration of the time interval.

The time $t_{k}$ from the beginning of the rainfall event to the $k$ th interval $\Delta T$ is expressed using Equation (3):

$$
t_{k}=k \cdot \Delta T, k=1,2,3 \ldots n
$$

This rainfall model mainly considers rainfall, the infiltration rate of different soils, and the drainage capacity of stormwater management systems in NYC. Therefore, the calculation equation of the runoff volume at time $t$ in this study is

$$
V_{t_{k}}=V_{t_{k-1}}+R_{k}-I_{k}-D_{k}
$$

where $V_{t_{k}}$ and $V_{t_{k-1}}$ are the runoff volume after the time interval $t_{k}$ and $t_{k-1}, R_{k}$ is the rainfall volume during time $\left(t_{k}, t_{k-1}\right), I_{k}$ is the infiltrated volume during time $\left(t_{k}, t_{k-1}\right)$, and $D_{k}$ is the volume of water drained through the sewer system during the time $\left(t_{k}, t_{k-1}\right)$. The infiltration volume was determined by the average infiltration rate and area of the soil. The infiltration rate depends on the soil conditions. Based on infiltration capacity, Decker and Westphalen proposed that the soil can be divided into four general conditions: good, medium, poor, and impervious [36]. The infiltration rate of different land conditions is shown in Table 1.

Table 1. Average infiltration rates for green space categories.

\begin{tabular}{cc}
\hline Green Space Condition & Average Infiltration Rate $\mathbf{( c m} / \mathbf{h})$ \\
\hline Good & 5.24 \\
Moderate & 0.63 \\
Poor & 0.035 \\
Impervious & 0 \\
\hline
\end{tabular}

The infiltrated volume during time $\left(t_{k}, t_{k-1}\right)$ is expressed as Equation (5):

$$
I_{k}=\Delta T \cdot\left(A_{b} f_{b}+A_{t} f_{t}+A_{g} f_{g}\right)
$$

where $f_{b}, f_{t}$, and $f_{g}$ are the average infiltration rates for bare soil, tree canopy, and grass, and $A_{b}, A_{t}$, and $A_{g}$ are the areas for bare soil, tree canopy, and green area in a sub-basin. Bare soil has more runoff and a poor infiltration condition, so $f_{b}=0.035 \mathrm{~cm} / \mathrm{h}$ (from Table 1). Tree canopy is in good condition, so $f_{t}=5.24 \mathrm{~cm} / \mathrm{h}$ (from Table 1). The grass is in moderate condition, so $f_{g}=0.63 \mathrm{~cm} / \mathrm{h}$ was considered (Table 1 ). The rainfall volume and the volume of water drained through the sewer system during the time $\left(t_{k}, t_{k-1}\right)$ are calculated as follows:

$$
\begin{aligned}
D_{k} & =d \cdot \Delta T \\
R_{k} & =r \cdot \Delta T
\end{aligned}
$$

where $r$ is the average rainfall intensity during $\Delta T$, and $d$ is the discharge rate of the drainage system of NYC. In the Stormwater Management Design Manual of New York, the stormwater system in New York is designed to deal with a 10 year rainfall [37]. According to the data provided by NOAA, $d$ is $36.322 \mathrm{~mm} / \mathrm{h}$ [38]. However, these data were produced for large scale flood analysis and might not provide the precise information required for complex urban flood analysis. The horizontal accuracy of the rainfall data may reach up to $5 \mathrm{~km}$ (3.11 miles) and significant sampling errors could also occur due to longer duration periods. After the runoff volume was obtained, the submerged depth can be queried in the database of the corresponding sub-basin.

\subsection{Modeling the Effect of Sea Level Rise}

We used the data developed by NOAA Coastal Management Office to analyze the effect of sea level rise on the WWTPs [39]. It can be used to access data and information 
about sea level rise, storm surges, and flood risks along the coast of the United States. To obtain more detailed inundation data, the shapefiles of flood depth at different heights, ranging from $0.31 \mathrm{~m}$ to $3.05 \mathrm{~m}(1$ to $10 \mathrm{ft})$ of sea level rise provided by NOAA, were downloaded for data analysis. Through the raster calculation tool of GIS, based on the $\mathrm{DEM}$, inundation maps at different heights (ranging from 1 to $10 \mathrm{ft}$ ) of sea level rise for all 889 sub-basins were be obtained. After obtaining the raster format file of the flood depth through these methods and then superimposing the raster according to the specific situation of the cascading event, the flood situation for each WWTP when the cascading event occurs was obtained.

\subsection{Economic Damage Estimation Model}

HAZUS-MH (multihazard) is widely used GIS-based software created by FEMA (Federal Emergency Management Agency) to evaluate the impact of disasters in urban and rural areas [13]. Government planners, GIS experts, and emergency management personnel use HAZUS-MH to determine losses and use the most favorable mitigation methods to minimize losses [40-42]. Accurate loss estimation gives timely emergency preparedness and disaster mitigation measures when a disaster occurs and provides a theoretical basis for subsequent recovery plans and government decisions. This study used the equations in HAZUS to estimate the damage caused by the flood to the WWTP. The damage caused by flooding is represented by the flood depth vs. damage curves. The total economic loss was later calculated by following Equation (8) [13]:

$$
(\$ \text { Loss })=(\% \text { Damage }) \times(\text { Inventory \$ Value })
$$

The damage functions are presented in Table 2.

Table 2. WWTPs classification, damage function, and economic valuation.

\begin{tabular}{ccccccccccccccc}
\hline \multirow{2}{*}{ WWTPs } & \multirow{3}{*}{ Capacity } & \multicolumn{1}{c}{ Damage (\%) by Depth of Flooding (in Feet) } & \multicolumn{3}{c}{$\begin{array}{c}\text { HAZUS Valuation } \\
\text { (in Thousands of USD) }\end{array}$} \\
\cline { 3 - 13 } & & $\mathbf{0}$ & $\mathbf{1}$ & $\mathbf{2}$ & $\mathbf{3}$ & $\mathbf{4}$ & $\mathbf{5}$ & $\mathbf{6}$ & $\mathbf{7}$ & $\mathbf{8}$ & $\mathbf{9}$ & $\mathbf{1 0}$ & 60,000 \\
Small WWTP & $<50$ & 0 & 5 & 8 & 10 & 17 & 24 & 30 & 30 & 30 & 30 & 40 & 200,000 \\
Medium WWTP & $20-200$ & 0 & 5 & 8 & 10 & 17 & 24 & 30 & 30 & 30 & 30 & 40 & 720,000 \\
Large WWTP & $>200$ & 0 & 5 & 8 & 10 & 17 & 24 & 30 & 30 & 30 & 30 & 40 & \\
\hline
\end{tabular}

Once the expected degree of damage was known in percentage (\%), it was multiplied by the replacement value to determine the amount of damage. The replacement value in HAZUS depends on the size of the WWTP. The size of the WWTP was defined by the design capability. The definition of plant size and replacement values are shown in Table 2. The probable economic damage termed as HAZUS valuation for each size of WWTP is also shown in Table 1. Based on the design capacity of 14 WWTPs in NYC, combined with this information provided by HAZUS, Table 3 was derived. Table 3 describes the economic damage for each of the WWTPs according to the damage estimation model from HAZUS. The depth-damage functions were later utilized to quantify the economic damage sustained by the WWTPs in USD.

After obtaining the inundation map of storm surge, high-intensity rainfall, and sea level rise, the submerged length of buildings in the WWTP was obtained through the measurement tool in GIS. The percentage of the submerged length in the perimeter of the entire WWTP and the amount of damage determined by the maximum submerged depth are essential bases for the definition of a WWTP in this study. Additionally, for this study's purpose, FEMA provided the data sets of Hurricane Sandy, which were retrieved from FEMA. For Hurricane Sandy, these data sets were in raster format, created by combining field-verified high-water marks and storm surge sensor data from the USGS. HWM (high water mark) and surge sensor data were used to interpolate the water surface elevation, and subtract it from the DEM [6]. 
Table 3. HAZUS valuation and damage function of 14 WWTPs in NYC.

\begin{tabular}{ccc}
\hline WWTPs & $\begin{array}{c}\text { Design Capacity } \\
\text { (MGD) }\end{array}$ & $\begin{array}{c}\text { HAZUS } \\
\text { Valuation } \\
\text { (Thousands of USD) }\end{array}$ \\
\hline Port Richmond & 60.0 & 200,000 \\
Oakwood Beach & 39.9 & 60,000 \\
Tallman Island & 80.0 & 200,000 \\
Rockaway & 45.0 & 60,000 \\
Jamaica & 100.0 & 200,000 \\
Bowery Bay & 150.0 & 200,000 \\
Hunts Point & 200.0 & 200,000 \\
Red Hook & 60.0 & 200,000 \\
Owls Head & 120.0 & 200,000 \\
Newtown Creek & 310.0 & 720,000 \\
Coney Island & 110.0 & 200,000 \\
26th Ward & 85.0 & 200,000 \\
North River & 170.0 & 200,000 \\
Wards Island & 275.0 & 720,000 \\
\hline
\end{tabular}

\section{Results}

\subsection{Case Study}

The Newtown Creek WWTP is taken as an example. The Newtown Creek WWTP, which is operated by the NYC DEP, is the largest in NYC [11]. It was built in 1967 and is located on Newtown Creek along Greenpoint Avenue in Brooklyn. The plant has a total of 88 employees and a design capacity of 310 MGD $\left(1173.35 \times 10^{6} \mathrm{~L} /\right.$ day $)$, providing wastewater treatment services for $1,068,012$ people on 15,656 acres [11]. It is in sub-basin 133. As shown in Figure 3a, the area is 5,067,975.8 square meters, including 29,164.3 square meters of bare soil, 582,010.2 square meters of tree canopies, and 375,189.3 square meters of grass. After a rainfall of $10.9 \mathrm{~cm} / \mathrm{h}$ for $20 \mathrm{~min}$, the flood elevation of sub-basin 133 is $2.4 \mathrm{~m}$ ( $8 \mathrm{ft}$ ) (Figure 3c). The storm surge brought by a C2 hurricane is 6 to 8 feet ( 1.8 to $2.4 \mathrm{~m})$. In this study, these two events and sea level rise of $8.0 \mathrm{ft}(\sim 2.4 \mathrm{~m})$ were regarded as events with similar conditions (Figure 3b). The rise in the water level they caused was all $8.0 \mathrm{ft}$ $(2.4 \mathrm{~m})$, as shown in Figure $3 \mathrm{~d}$. By comparing the percentage of the submerged length of the WWTP and the amount of damage in these three events, it can be judged which one had a greater impact on the plant.

Figure 4 provides the inundation maps of the Newtown Creek WWTP under similar conditions. According to the inundation map shown in Figure 3 and measuring the outline length of the buildings shown in Figure 4, Table 4 was developed. Table 4 shows the impact of the three events on the WWTP.

Table 4. Percentage of the submerged length and maximum flood depth for Newtown Creek WWTP and amount of damage in three events.

\begin{tabular}{cccccc}
\hline $\begin{array}{c}\text { Newtown Creek } \\
\text { WWTP }\end{array}$ & $\begin{array}{c}\text { Building } \\
\text { Perimeter (m) }\end{array}$ & $\begin{array}{c}\text { Submerged } \\
\text { Length }(\mathbf{m})\end{array}$ & $\begin{array}{c}\text { Submerged } \\
\text { Length }\end{array}$ & $\begin{array}{c}\text { Submerged } \\
\text { Depth (ft) }\end{array}$ & $\begin{array}{c}\text { Damage (Thousands } \\
\text { of USD) }\end{array}$ \\
\hline Storm Surge (C2) & $18,381.72$ & $16,934.28$ & $92.13 \%$ & 9.65 & 288,000 \\
Rainfall $(10.9 \mathrm{~cm} / \mathrm{h}$ & $18,381.72$ & 624.46 & $3.40 \%$ & 1.31 & 36,000 \\
$\quad$ for 20 min) & $18,381.72$ & 7014.86 & $38.16 \%$ & 3.81 & 122,400 \\
Sea Level Rise (8ft) & & & & \\
\hline
\end{tabular}




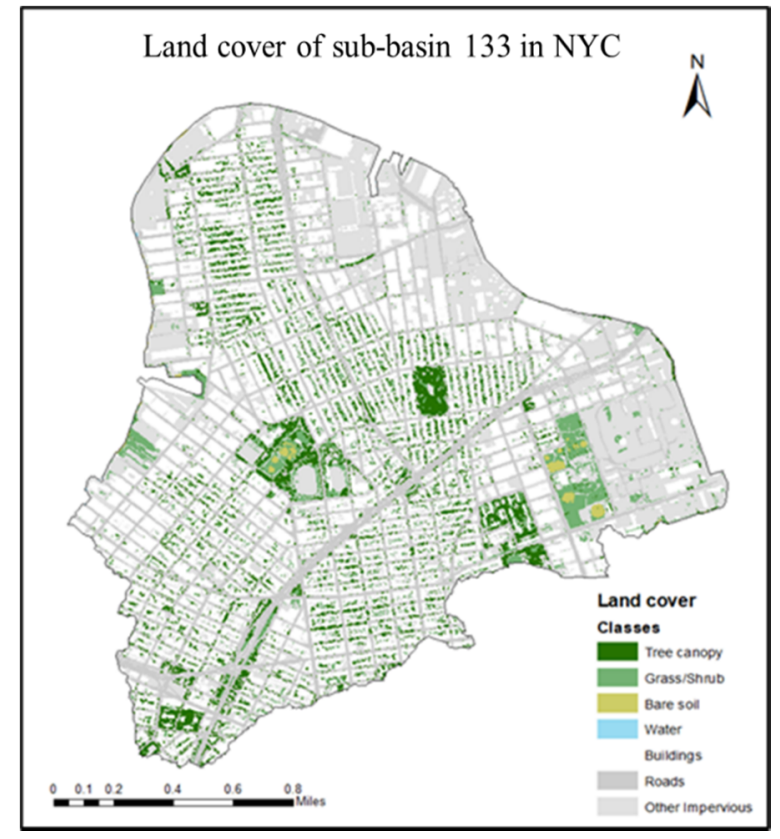

(a)

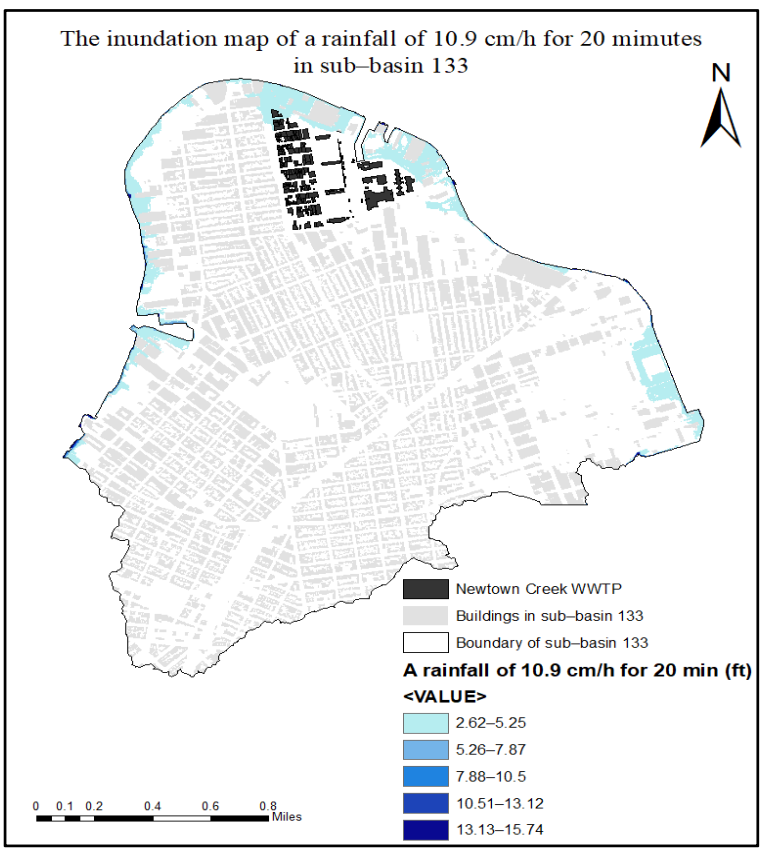

(c)

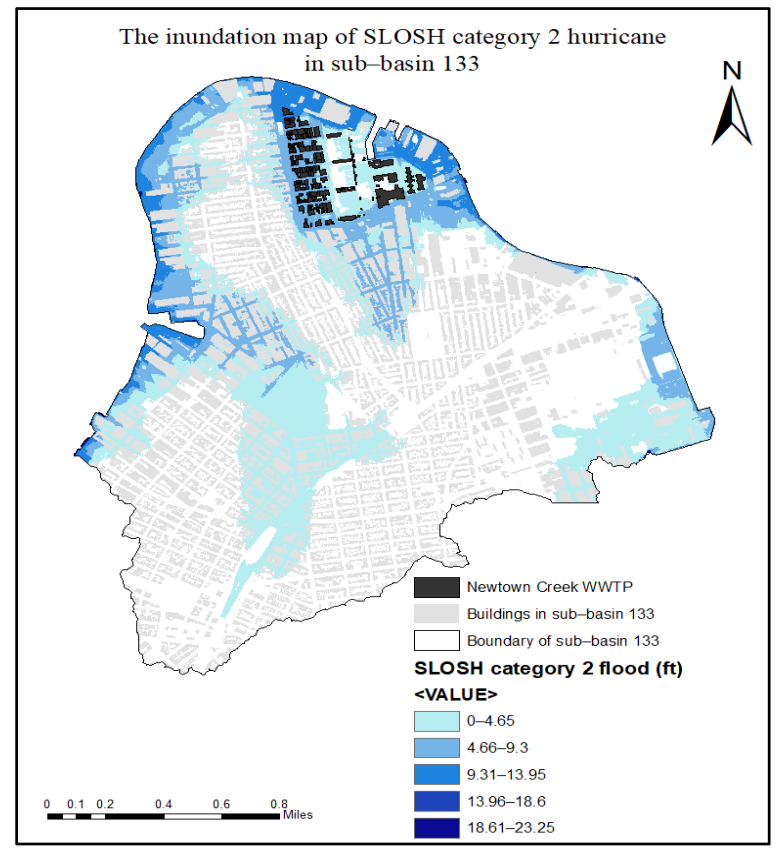

(b)

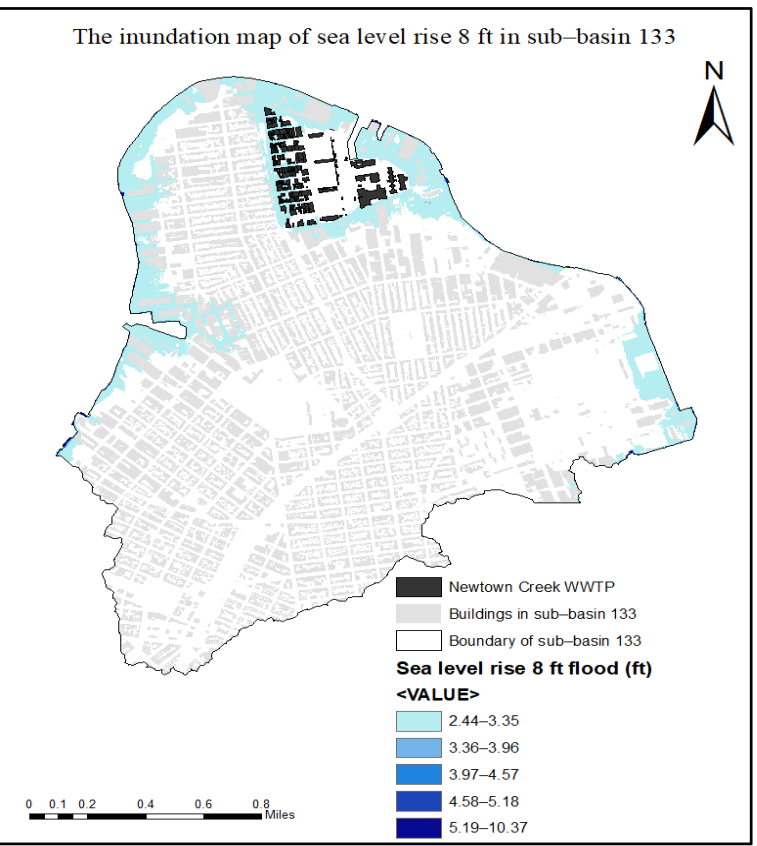

(d)

Figure 3. (a) Land cover of sub-basin 133 in NYC, (b-d) inundation maps of SLOSH category 2 hurricane, a rainfall of 10.9 $\mathrm{cm} / \mathrm{h}$ for $20 \mathrm{~min}$, and sea level rise of $2.44 \mathrm{~m}(8 \mathrm{ft})$ in sub-basin 133.

Our study showed that the amount of damage caused by storm surge was the largest, followed by sea level rise, and the least amount of damage was caused by high-intensity rainfall. The amount of damage caused by storm surge was 2.4 times greater than that caused by sea level rise, and 27.1 times that caused by high-intensity rainfall. When considering the inundation around the building footprint, results also indicated that the storm surge caused the largest percentage of flooding, followed by high-intensity rainfall. Whether from the perspective of the percentage of submerged length in the total perimeter of the buildings or the amount of damage, the storm surge undoubtedly caused a greater impact on the WWTP. Therefore, the storm surge poses a huge challenge to the Newtown 
Creek WWTP. In future disaster prevention research and decision-making, this event should be given special attention.

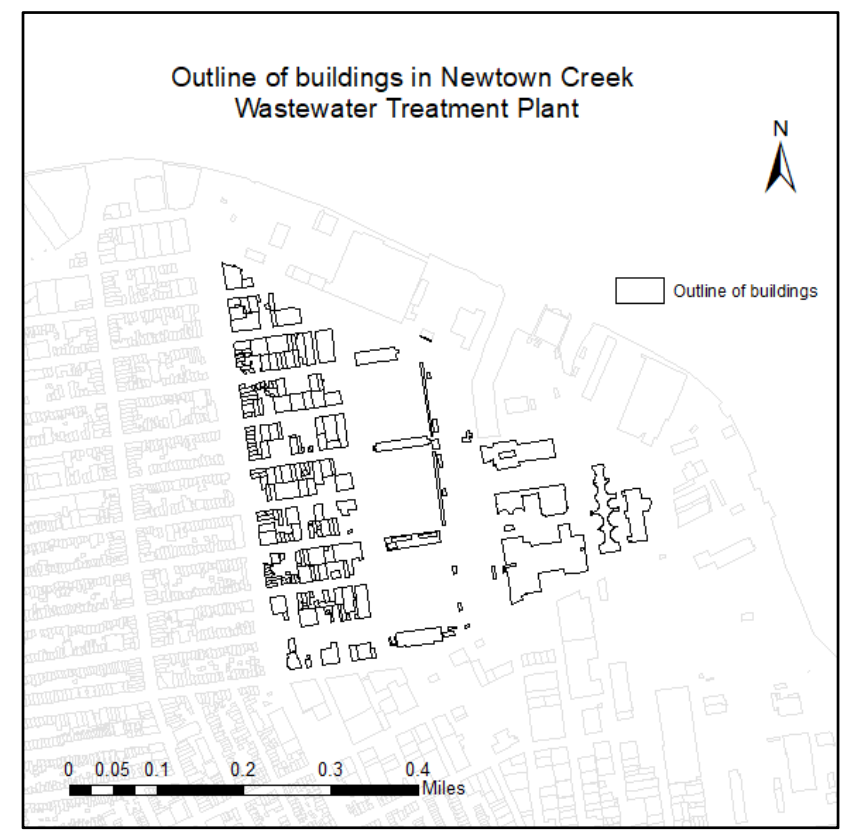

Figure 4. Outline of buildings in Newtown Creek WWTP.

\subsection{Comprehensive Study}

Based on the percentage of the submerged length of the buildings to the total perimeter of the buildings and the amount of damage, a chart was developed (Figure 5) to comprehensively analyze the impact of the storm surge, high-intensity rainfall, and sea level rise that caused the water level to rise $8 \mathrm{ft}(2.4 \mathrm{~m})$ on the 14 WWTPs in NYC. The higher these two values are, the greater the impact of the event on the WWTP.

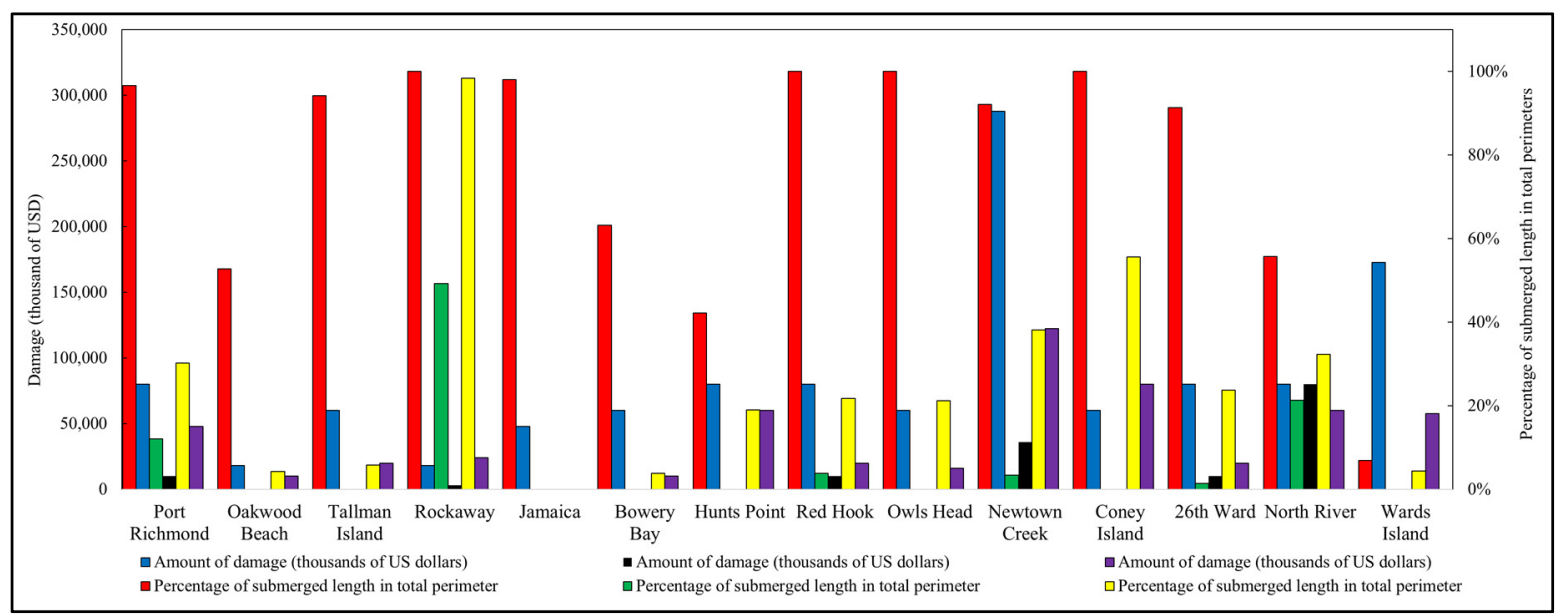

Figure 5. Percentage of the submerged length of buildings to the total perimeter of buildings and amount of damage caused by storm surge, high-intensity rainfall, and sea level rise.

According to the model, as shown in Figure 5, when the storm surge reached $2.44 \mathrm{~m}$ $(8 \mathrm{ft})$, all buildings of the Rockaway WWTP, Red Hook WWTP, Owls Head WWTP, and Coney Island WWTP were 100\% flooded. Among the 14 WWTPs, during hurricane C2, the storm surge caused the highest amount of damage to the Newtown Creek WWTP, at a cost of USD 288 million. As shown in Figure 5, after the rainfall intensity of $10.9 \mathrm{~cm} / \mathrm{h}$ lasted for 
$20 \mathrm{~min}$, all buildings in 8 of the 14 WWTPs were not significantly flooded: Oakwood Beach WWTP, Tallman Island WWTP, Jamaica WWTP, Bowery Bay WWTP, Hunts Point WTTP, Owls Head WWTP, Coney Island WWTP, and Wards Island WWTP were not submerged. Figure 5 also shows the impact of a sea level rise of $2.44 \mathrm{~m} \mathrm{(8.0)} \mathrm{ft}$ on 14 WWTPs in NYC. The most obvious is that the percentage of the Rockaway WWTP submerged was 98.34\%, far exceeding the percentages of submergence for the other WWTPs. However, among the 14 plants, the largest amount of damage occurred at the Newtown Creek WWTP, which was 5.1 times greater than that of Rockaway WWTP. In the end, the Jamaica WWTP was not affected at all. According to this figure, the most significant observation is that the impact of storm surges on NYC's WWTPs is greater than that of the high-intensity rainfall and sea level rise. The storm surge caused damage to all 14 WWTPs. However, the heavy rainfall only caused damage to 6 of the 14 WWTPs. Sea level rise caused relatively minor damage to WWTPs, with only one of the 14 plants remaining unaffected. It indicates that the formulation of preventive measures and response plans for storm surges should be a higher priority than high-intensity rainfall and sea level rise. To further compare which event of storm surge, high-intensity rainfall, or sea level rise has a greater impact on WWTPs, this study also developed Figure 6a,b. Figure 6a shows that the percentage of submerged length caused by storm surge is always the largest, while the percentage of submerged length caused by high-intensity rainfall is always the smallest. In addition, as shown in Figure $6 \mathrm{~b}$, from the perspective of damage, the amount of damage caused by storm surge is always the largest, while the amount of flooding caused by high-intensity rainfall is always the smallest. Except for the Rockaway WWTP, Coney Island WWTP, and North River WWTP, the other WWTPs follow the rule that the amount of damage caused by storm surge is the largest and the amount of damage caused by high-intensity rainfall is the smallest. This information indicated that the storm surge causes major challenges to WWTPs. Researchers and the government should increase the research and prevention of storm surges to cope with the occurrence of future storm surges and provide a sufficient basis for pre-disaster prevention and post-disaster recovery.

\subsection{Comparison between SLOSH and MOTF Study}

Through the research method proposed in this paper and the data provided by FEMA MOTF, the inundation maps of FEMA MOTF Sandy in NYC were obtained. Sub-basin 133 was taken as an example; Figure 7 presents the inundation map of FEMA MOTF Sandy in sub-basin 133. Combining the inundation map of FEMA MOTF Sandy and the previously obtained inundation map of SLOSH C1 and C2 hurricanes, this study compared the data obtained from the maps. The flood depths of 11 of 14 WWTPs in FEMA MOTF Sandy were greater than those of the SLOSH C1 hurricane, and 10 of them were greater than those of the SLOSH C2 hurricane. Similar flood depth was observed by Olyaei et al. who used a hydrodynamic model to simulate the flood inundation due to Hurricane Sandy for Coney Island WWTP [43]. We also wanted to highlight the fact that, although Hurricane Sandy reached a maximum strength of category 2 hurricane, it was only with the strength of a tropical storm (TS) during its landfall along the east coast of the United States. This means that other factors affect the flooding of WWTPs, such as heavy rainfall. Therefore, in the next section, this study analyzes cascading events. 


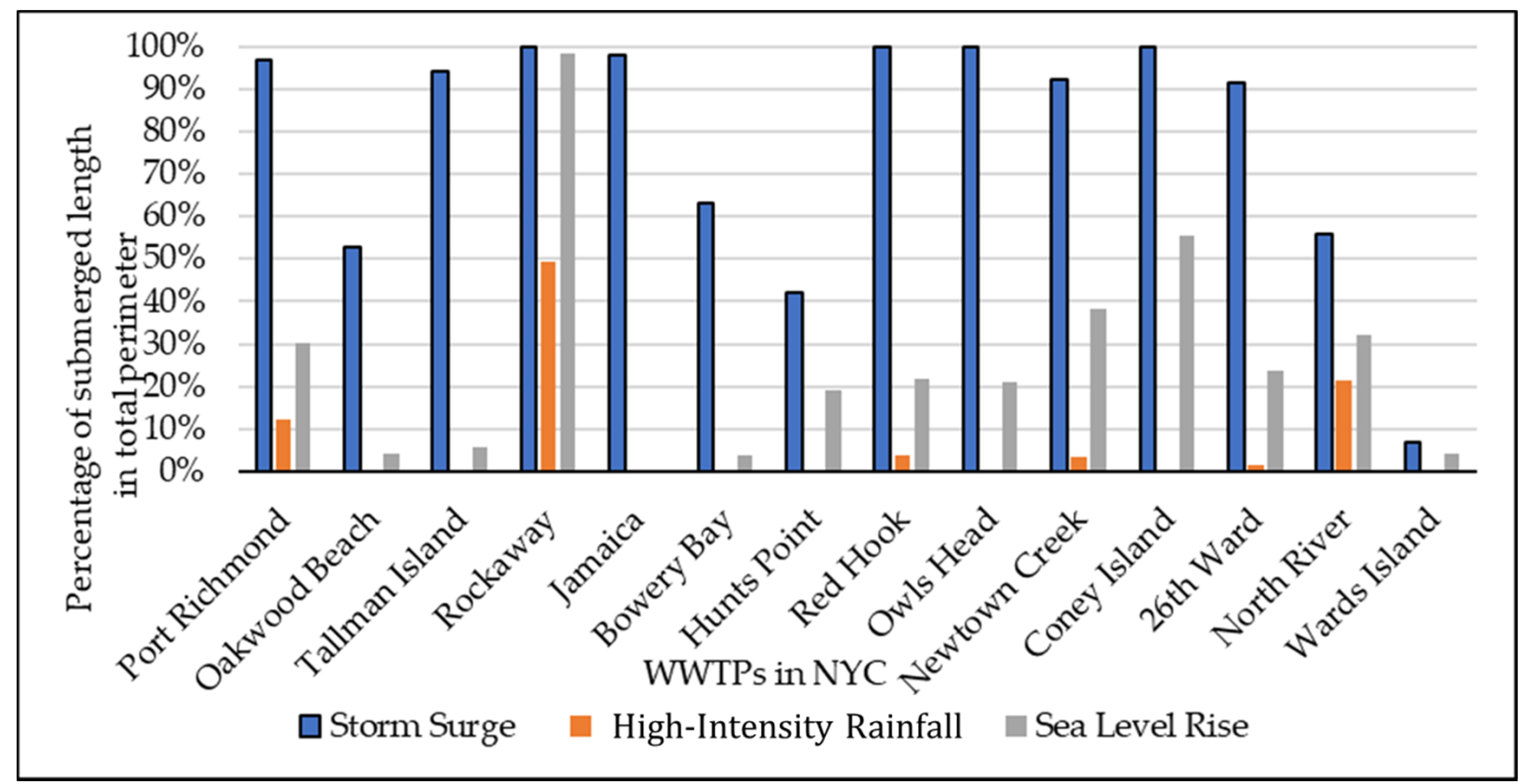

(a)

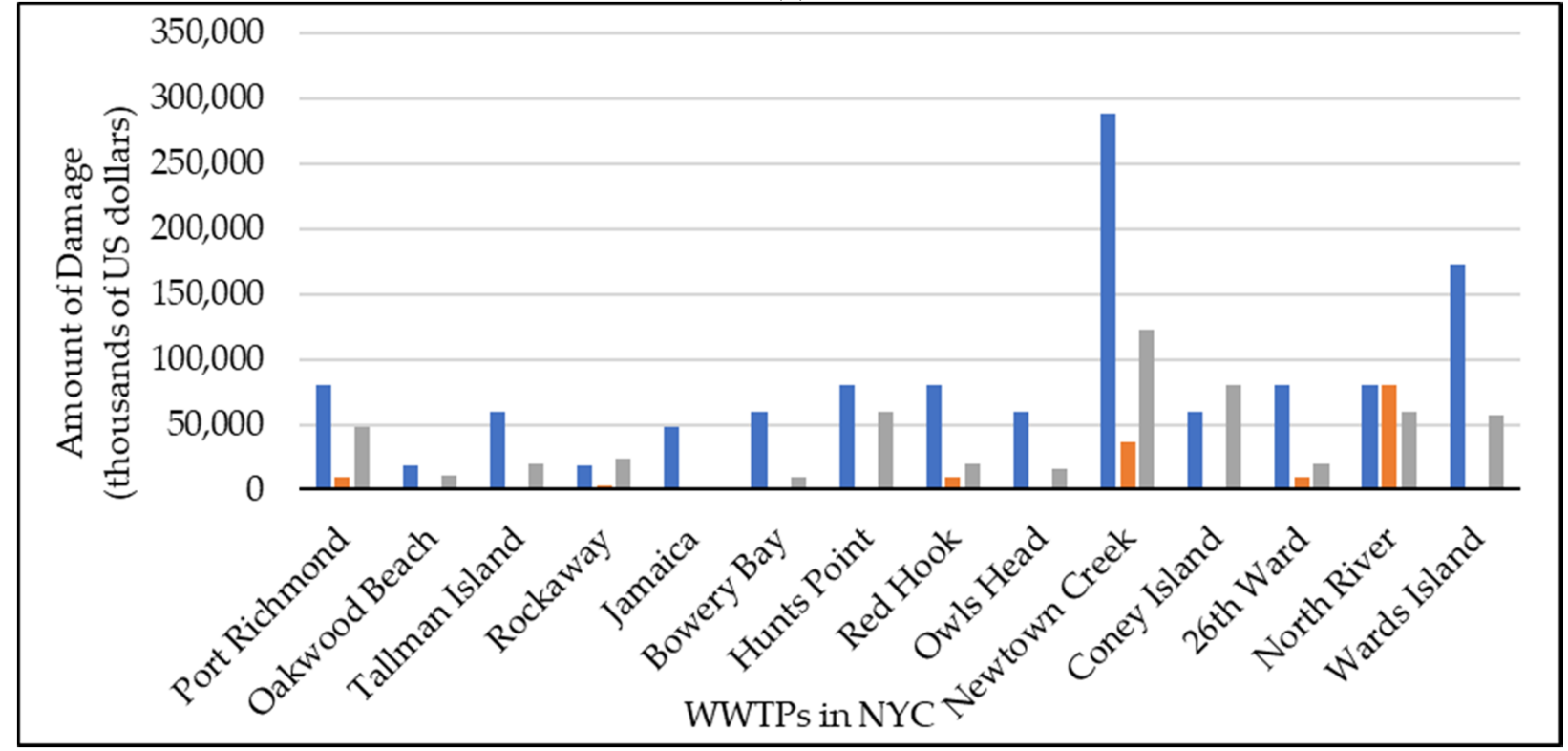

(b)

Figure 6. (a) Percentage of submerged length caused by three extreme events to 14 WWTPs and (b) amount of damage caused by three extreme events to 14 WWTPs. 


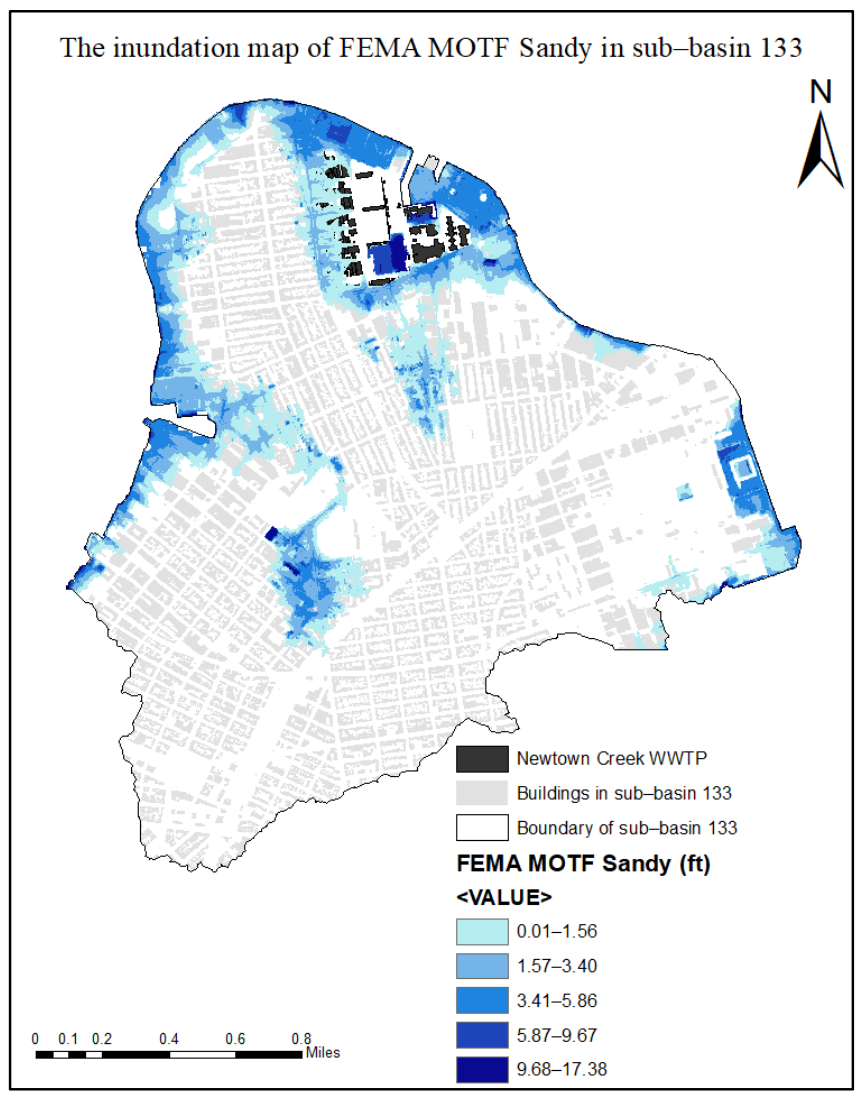

Figure 7. The inundation map of FEMA MOTF Sandy in sub-basin 133.

Table 5 shows that in the data of Hurricane Sandy provided by FEMA MOTF, some WWTPs had relatively large flood depths, but the proportion of their buildings being submerged was not large. For example, the Hunts Point WWTP had a flood depth of $13.17 \mathrm{~m}$, which was almost twice the flood depth of the C2 hurricane, but only $2.29 \%$ of the plant was flooded due to Sandy, which was far less than the $42.2 \%$ caused by the C2 hurricane.

Table 5. Comparison of maximum flood depth between FEMA MOTF Sandy, SLOSH C1, and C2 hurricanes.

\begin{tabular}{ccccccc}
\hline \multirow{2}{*}{$\begin{array}{c}\text { WWTPs } \\
\text { in NYC }\end{array}$} & $\begin{array}{c}\text { Sercentage of } \\
\text { the Submerged } \\
\text { Length }\end{array}$ & $\begin{array}{c}\text { Flood Depth } \\
(\mathbf{m})\end{array}$ & $\begin{array}{c}\text { Percentage of } \\
\text { the Submerged } \\
\text { Length }\end{array}$ & $\begin{array}{c}\text { Flood Depth } \\
\text { (m) }\end{array}$ & $\begin{array}{c}\text { Percentage of } \\
\text { the Submerged } \\
\text { Length }\end{array}$ & $\begin{array}{c}\text { Flood Depth } \\
\text { (m) }\end{array}$ \\
\hline Port Richmond & $50.23 \%$ & 3.83 & $96.66 \%$ & 9.54 & $34.92 \%$ & 5.91 \\
Oakwood Beach & $13.55 \%$ & 1.54 & $52.75 \%$ & 7.78 & $38.60 \%$ & 15.54 \\
Tallman Island & $7.94 \%$ & 0.46 & $94.25 \%$ & 6.66 & $16.35 \%$ & 13.08 \\
Rockaway & $68.28 \%$ & 2.33 & $100 \%$ & 9.42 & $100 \%$ & 13.9 \\
Jamaica & $0.00 \%$ & 0 & $98.09 \%$ & 4.67 & $0.00 \%$ & 0 \\
Bowery Bay & $3.37 \%$ & 0.24 & $63.19 \%$ & 6.46 & $5.70 \%$ & 2.07 \\
Hunts Point & $2.74 \%$ & 0.35 & $42.20 \%$ & 6.55 & $29 \%$ & 13.17 \\
Red Hook & $20.53 \%$ & 4.58 & $100 \%$ & 10.62 & $21.75 \%$ & 3.46 \\
Owls Head & $24.57 \%$ & 1.42 & $100 \%$ & 7.89 & $31.59 \%$ & 11.47 \\
Newtown Creek & $59.47 \%$ & 3.73 & $92.13 \%$ & 9.65 & $46.35 \%$ & 17.38 \\
Coney Island & $0.00 \%$ & 0 & $100 \%$ & 7.22 & $50.38 \%$ & 13.04 \\
26th Ward & $1.21 \%$ & 1.83 & $91.36 \%$ & 12.48 & $28.01 \%$ & 13.15 \\
North River & $7.66 \%$ & 12.84 & $55.71 \%$ & 19 & $50.52 \%$ & 11.11 \\
Wards Island & $0.00 \%$ & 0 & $6.94 \%$ & 5.1 & $5.25 \%$ & 7.03 \\
\hline
\end{tabular}


In addition, this study used the amount of damage in the evaluation equation in HAZUS to develop the data provided in Table 6.

Table 6. Comparison of the amount of damage related to the FEMA MOTF Sandy, SLOSH C1, and C2 hurricanes.

\begin{tabular}{cccc}
\hline \multirow{2}{*}{ in NYPs } & \multicolumn{2}{c}{ Amount of Damage (Thousands of USD) } \\
\cline { 2 - 4 } & SLOSH C1 & SLOSH C2 & FEMA Sandy \\
\hline Port Richmond & 34,000 & 80,000 & 60,000 \\
Oakwood Beach & 4800 & 18,000 & 24,000 \\
Tallman Island & 0 & 60,000 & 80,000 \\
Rockaway & 4800 & 18,000 & 24,000 \\
Jamaica & 0 & 48,000 & 0 \\
Bowery Bay & 0 & 60,000 & 60,000 \\
Hunts Point & 0 & 80,000 & 80,000 \\
Red Hook & 34,000 & 80,000 & 20,000 \\
Owls Head & 10,000 & 60,000 & 80,000 \\
Newtown Creek & 122,400 & 288,000 & 288,000 \\
Coney Island & 0 & 60,000 & 80,000 \\
26th Ward & 16,000 & 80,000 & 80,000 \\
North River & 80,000 & 80,000 & 80,000 \\
Wards Island & 0 & 172,800 & 216,000 \\
\hline SUM & 306,000 & $1,184,800$ & $1,172,000$ \\
\hline
\end{tabular}

As seen in Table 6, through FEMA MOTF Sandy, SLOSH C1, and C2 hurricanes, the total damage of 14 WWTPs was USD 1.172 billion, 1.1848 billion, and 306 million, respectively. A study conducted by Karamouz et al. also found similar flood depth for the WWTPs in NYC where the flood depth simulated by HAZUS for different return periods of flooding for Hunts Point WWTP [44]. The amount of damage estimated based on the data provided by FEMA MOTF Sandy is closer to the amount of damage obtained in the SLOSH C2 hurricane. This highlights the severity of damage the WWTPs would sustain under strong hurricanes such as C2 or more. However, the study showed that six WWTPs sustained more damage as simulated by SLOSH category 2 hurricane than the observed FEMA MOTF inundation. As the SLOSH model provides the highest storm surge value considering maximum tidal elevation, it can be considered as a synthetic storm to show the maximum flooding, both in terms of depth and extent, for a certain category of hurricane. In addition, products from SLOSH inundation mapping do not include the influence of river flow or rainfall-induced flooding. Therefore, a direct comparison of SLOSH inundation maps with FEMA MOTF would not be possible. However, SLOSH can provide the information about the maximum storm surge level due to various categories of hurricanes only. Therefore, a complete flood analysis for the WWTPs needs to include the influence of storm surge and riverine flooding. On the other hand, FEMA MOTF provides the inundation maps based on observation, which were used to compare the flood depth and extent with model-simulated inundation, such as from the SLOSH C2 hurricane. Both inundation maps were generated using the high-resolution DEM, but due to the inherent difference between the data generation SLOSH C2 inundation maps were different compared to the observed FEMA MOTF maps for Hurricane Sandy.

\subsection{Cascading Events}

In recent years, the main damage caused by storm surges, high-intensity rainfall, and sea level rise has often come from the cascade of these events rather than a single strong factor [6]. The impact of storms on WWTPs is also a result of a cascade of storm surge, sea level rise, and rainfall. Therefore, this study also explored the impact of the three-factor cascading event on the buildings of the WWTP based on the sub-basin. Through GIS, this study analyzed the flood depth when a cascade event of 100 years of rainfall, sea level rise, and storm surge C1 occurred in 2050, which was used to evaluate the impact 
of the cascade event on the NYC WWTPs. Sea level will rise by 7 to 12 inches [18], and the intensity of the 100 year rainfall in 2050 is $4.14 \mathrm{in} / \mathrm{h}(10.52 \mathrm{~cm} / \mathrm{h})$ as projected by the New York State Energy Research and Development Authority (NYSERDA). A study conducted by Rosenzweig et al. also utilized similar sea level rise trends to develop coastal adaptation to climate change in NYC [45]. This analysis can help understand which factor plays a more significant role in the flood caused by cascading events. The study utilized the linear summation of the constituents to simulate the extreme flooding events for the WWTPs based on the total water level (TWL) concept. Several studies have also adopted similar methodology to simulate the extreme total water levels. For example, research conducted by Serafin and Ruggiero (2014) simulated the elevation of the TWL considering linear summation of four different component (i.e., storm surge, sea level rise, rainfall, and wave run-up) to explain the total contribution from mean sea level, astronomical tides, wave run-up, and nontidal residuals [46]. Therefore, the present study utilized a similar approach to quantify the total water level.

Table 7 shows the maximum total flood depth in 2050 when the 100-year rainfall, sea level rise, and storm surge C1 occurred simultaneously. Although a hydrodynamic model would be necessary to get the precise assessment of flood depth and inundation extent based on cascading events, this study presents a preliminary estimation of flood depth due to the contribution of extreme events occurring simultaneously. Results showed that storm surge had the largest impact on the flood depth around the WWTP. The rainfall only affected the Port Richmond WWTP and the Newtown Creek WWTP. However, sea level rise had no impact on the 14 WWTPs according to our study, but a more comprehensive approach with hydrodynamic modeling must be conducted with proper boundary conditions to further justify the outcome from the cascading events.

Table 7. Estimation of the potential magnitude of flood depth due to the compounded effect of high-intensity rainfall, sea level rise, and storm surge.

\begin{tabular}{ccccc}
\hline WWTP & $\begin{array}{c}\text { Total Flood } \\
\text { Depth/ft }\end{array}$ & $\begin{array}{c}\text { Rainfall } \\
\mathbf{1 0 0} \mathbf{~ y r / f t}\end{array}$ & $\begin{array}{c}\text { Sea Level Rise } \\
\mathbf{1} \mathbf{f t} / \mathbf{f t}\end{array}$ & $\begin{array}{c}\text { Strom Surge } \\
\mathbf{C} \mathbf{1} / \mathbf{f t}\end{array}$ \\
\hline Port Richmond & 13.96 & 6.89 & 0 & 7.07 \\
Oakwood Beach & 1.54 & 0 & 0 & 1.54 \\
Tallman Island & 0.46 & 0 & 0 & 0.46 \\
Rockaway & 2.33 & 0 & 0 & 2.33 \\
Jamaica & 0 & 0 & 0 & 0 \\
Bowery Bay & 0.24 & 0 & 0 & 0.24 \\
Hunts Point & 0.35 & 0 & 0 & 0.35 \\
Red Hook & 4.62 & 0 & 0 & 4.62 \\
Owls Head & 1.42 & 0 & 0 & 1.42 \\
Newtown Creek & 4.06 & 0.33 & 0 & 3.73 \\
Coney Island & 0 & 0 & 0 & 0 \\
26th Ward & 1.83 & 0 & 0 & 1.83 \\
North River & 2.92 & 0 & 0 & 2.92 \\
Wards Island & 0 & 0 & 0 & 0 \\
\hline
\end{tabular}

\section{Discussion}

The main feature of this study was that the WWTPs could be considered as a building rather than a point. To further compare the difference between the inundation maps obtained by considering WWTPs as buildings and points, this study also used the same data source, taking the WWTP as a point on the map to obtain the inundation maps of 14 WWTPs in NYC. Taking the storm surge as an example, Table 8 shows the flood depth obtained from the inundation map of a SLOSH category 2 hurricane when the WWTP is regarded as a point and a building. Research conducted by McAllister also reported a similar surge level at King's Point on Long Island and at Battery Park in Lower Manhattan [47]. In the flood analysis of the WWTP, the storm surge inundation map obtained by treating the WWTP as a point does not fully show the inundation status of the 
WWTP. In addition to the inability to show which areas of the WWTP are submerged, it is also unable to have deviations in the flood depth.

Table 8. Comparison when considering WWTPs as points vs. buildings for a SLOSH category 2 hurricane.

\begin{tabular}{cccc}
\hline WWTPs & Points & \multicolumn{2}{c}{ Buildings } \\
\cline { 2 - 4 } & Flood Depth (ft) & $\begin{array}{c}\text { Minimum Flood } \\
\text { Depth (ft) }\end{array}$ & $\begin{array}{c}\text { Maximum Flood } \\
\text { Depth (ft) }\end{array}$ \\
\hline Port Richmond & 6.27 & 2.95 & 9.54 \\
Oakwood Beach & 7.65 & 1.19 & 7.78 \\
Tallman Island & 0.10 & 0.09 & 6.66 \\
Rockaway & 6.13 & 2.79 & 9.42 \\
Jamaica & 4.63 & 1.32 & 4.67 \\
Bowery Bay & $\backslash$ & 3.11 & 6.46 \\
Hunts Point & 6.53 & 3.23 & 6.55 \\
Red Hook & 0.96 & 0.79 & 10.62 \\
Owls Head & 4.58 & 1.31 & 7.89 \\
Newtown Creek & $\backslash$ & 2.90 & 9.65 \\
Coney Island & 7.12 & 3.78 & 7.22 \\
26th Ward & 5.9 & 2.33 & 12.48 \\
North River & $\backslash$ & 2.35 & 19.00 \\
Wards Island & $\backslash$ & 1.71 & 5.10 \\
\hline
\end{tabular}

Similar flood depth was also found by Karamouz et al., which showed a flood depth

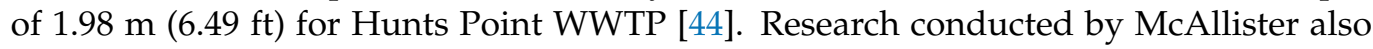
reported that the flood elevations for the affected WWTP during hurricane Sandy exceeded the flood depth outlined by FEMA flood maps, and the 100 year flood elevation [47]. As shown in Table 8, the flood depth obtained when the WWTP is regarded as a point has only one value, mostly between the maximum and minimum flood depths obtained when the WWTP is regarded as a building. A study conducted by Olyaei et al. also pointed out major damage for the WWTP infrastructures with the WWTP with Coney Island being damaged the most [43]. However, there are exceptions, such as the Newtown Creek WWTP. When the WWTP is regarded as a point, it was shown that it had not encountered floods, but in fact, the maximum flood depth of the Newtown Creek WWTP was $9.65 \mathrm{ft}$, the minimum flood depth is $2.90 \mathrm{ft}$, and the percentage of submerged length is $92.13 \%$. The Bowery Bay WWTP, North River WWTP, and Wards Island WWTP also have the same problem. In addition, the division of NYC into 889 sub-basins also has apparent advantages in calculating runoff. NYC covers a very large area. When it encounters unevenly distributed rainfall, if the entire NYC is used to calculate the runoff, the accuracy of the resulting flood maps and data is reduced. In this study, a 20 min rainfall event with an average rainfall intensity of $10.9 \mathrm{~cm} / \mathrm{h}$ was used as an example to compare the inundation maps and data obtained by dividing NYC into sub-basins and not dividing it into sub-basins. Taking the Newtown Creek WWTP as an example, Table 9 shows the difference in flood elevation and flood depth obtained by dividing and not dividing sub-basins when calculating runoff. 
Table 9. Calculated runoff volume with and without sub-basins.

\begin{tabular}{ccc}
\hline Newtown Creek WWTP & Without Sub-Basin (NYC) & $\begin{array}{c}\text { With Sub-Basin (Sub-Basin } \\
\text { 133) }\end{array}$ \\
\hline Area of Bare Soils $/ \mathrm{m}^{2}$ & $10,262,756.5$ & $29,164.3$ \\
Area of Tree Canopy $/ \mathrm{m}^{2}$ & $158,648,274.6$ & $582,010.2$ \\
Area of Grass or Shrubs $/ \mathrm{m}^{2}$ & $141,279,429.4$ & $375,189.3$ \\
Total Area $/ \mathrm{m}^{2}$ & $782,750,587.5$ & $5,067,975.8$ \\
Runoff Volume $/ \mathrm{m}^{3}$ & $16,160,876.3$ & $114,997.8$ \\
Flood Elevation $/ \mathrm{m}$ & 0.6 & 2.4 \\
Flood Depth $/ \mathrm{ft}$ & 0.0 & 1.31 \\
\hline
\end{tabular}

Analysis showed that the proportion of green space in NYC is greater than the proportion of green space in sub-basin 133. The proportion of green space affects the infiltration volume and, thus, the runoff volume. Figure 8 shows the inundation map of the Newtown Creek WWTP under a 20 min rainfall event with and without sub-basins. The difference is noticeable. When calculating runoff without dividing NYC into 889 sub-basins, the inundation map shows that the Newtown Creek WWTP did not flood, but after dividing the sub-basins, the maximum flood depth of this plant reached $1.31 \mathrm{ft}$. Because different types of green space are not evenly distributed, soil infiltration capacity in different areas of NYC is also different. It is easily observed that dividing the city into sub-basins provides more accurate rainfall inundation results.
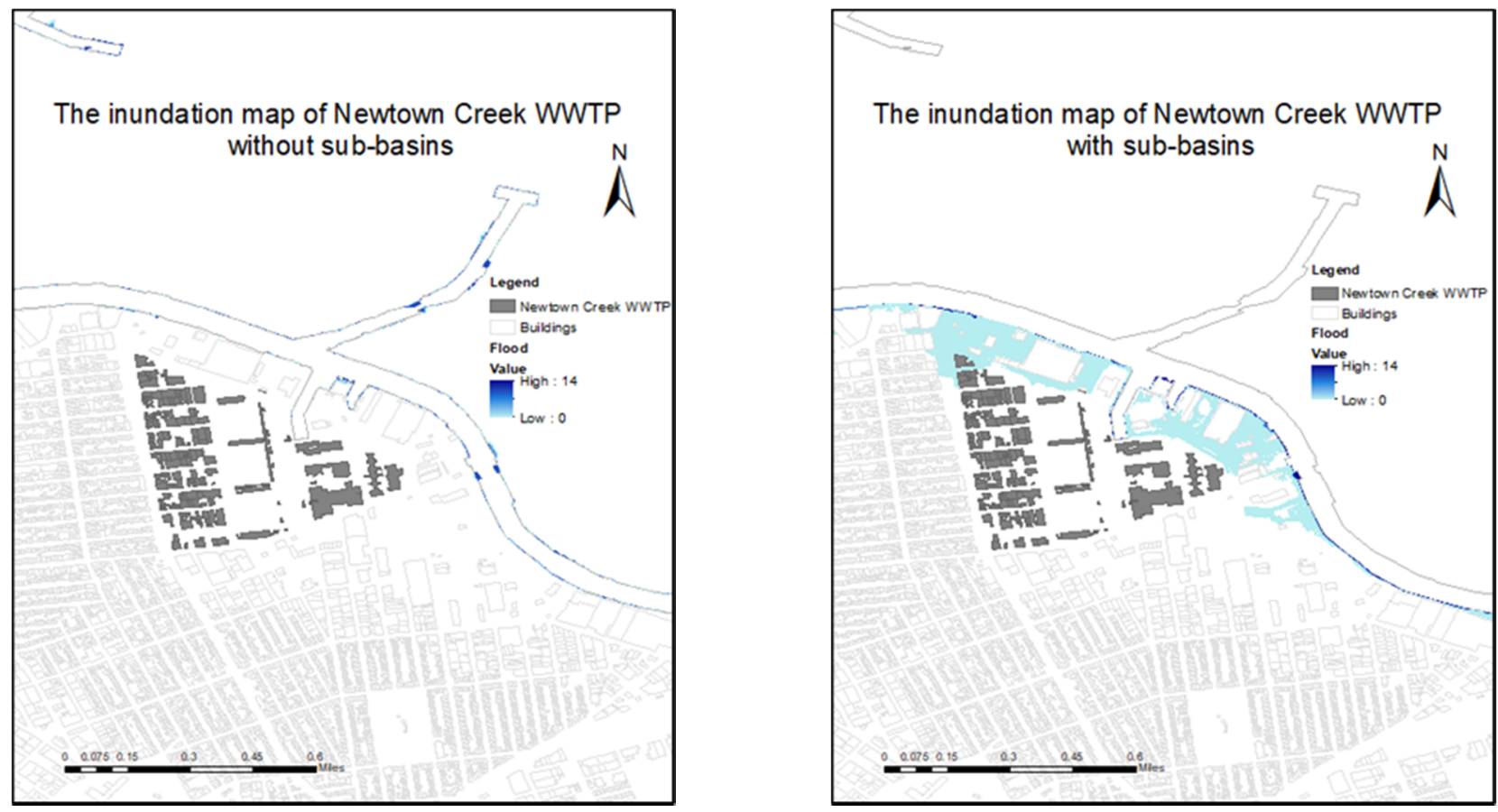

Figure 8. Comparison of inundation map of Newtown Creek WWTP under a $20 \mathrm{~min}$ rainfall event without and with sub-basins.

\section{Conclusions}

The main purpose of this study was to provide a new perspective for evaluating the impact of three extreme events on the NYC WWTPs based on the sub-basins. It measured and compared the submerged length of all buildings within the WWTPs and the percentage of the submerged length to the total perimeter of all buildings. Additionally, the formula for calculating the amount of damage in HAZUS was used to evaluate the amount of damage. These two values have become important factors in evaluating the impact of flooding scenarios. By comparison, this study did find that the sub-basin is crucial for analyzing 
the inundation situation. Generally, when the inundation situation is analyzed under high-intensity rainfall, the inundation situation obtained is more accurate. In addition, certain areas can be analyzed in a targeted manner to reduce the workload. Moreover, by analyzing the inundation situation of the buildings themselves, researchers acquire a clearer understanding of the WWTP's actual flooding situation rather than a single value at a particular point. The methodology not only provides more details for describing the flood encountered by the WWTP, but also determines which buildings are affected by the flood, which can help the government take preventive measures in advance.

The results also show that when the height of the water level rise caused by storm surge, high-intensity rainfall, and sea level rise was similar, the storm surge has a greater impact on the WWTP and causes more damage. Moreover, as expected, WWTPs close to the coastline are more vulnerable to flooding than those more inland plants, such as the Rockaway WWTP. In the analysis for WWTPs in NYC impacted by extreme events, the results indicate the largest impacts are due to storm surge, followed by high-intensity rainfall, and lastly by sea level rise.

Through the sub-basin database and inundation maps established by this research, more inundation data can be generated to analyze the impact of other extreme events of varying degrees on WWTPs. Additionally, the sub-basin database also provides support for studying flood conditions when cascading events occur. Based on this database, the damage degree of WWTPs can be assessed when different events occur simultaneously. These data can provide the theoretical basis for future research and government decision-making so that citizens can respond to extreme events in a timely and correct manner. The study focused on the compound effect of different types of extreme events including rainfall, sea level rise, hurricanes, etc. Future extension of this work will include hydrodynamic modeling of the study area by integrating different boundary conditions such as rainfall, tides, storm surge, etc. to depict an accurate representation of flood extent within the WWTPs.

Author Contributions: Conceptualization, Q.S. and R.N.; methodology, R.N. and M.K.; software, Q.S., R.N. and M.G.R.F.; validation, R.N. and M.G.R.F.; formal analysis, Q.S.; investigation, Q.S.; resources, R.N.; data curation, Q.S.; writing—original draft preparation, Q.S. and R.N.; writingreview and editing, R.N., M.K. and R.W.P.; visualization, Q.S.; supervision, R.N. and M.K.; project administration, R.N.; funding acquisition, R.N. All authors have read and agreed to the published version of the manuscript.

Funding: This research received no external funding.

Institutional Review Board Statement: Not applicable.

Informed Consent Statement: Not applicable.

Data Availability Statement: Data were generated at a central, large-scale facility and available upon request.

Conflicts of Interest: The authors declare no conflict of interest.

\section{References}

1. Hossain, M.K.; Meng, Q. A fine-scale spatial analytics of the assessment and mapping of buildings and population at different risk levels of urban flood. Land Use Policy 2020. [CrossRef]

2. Sabrin, S.; Karimi, M.; Fahad, M.G.R.; Nazari, R. Quantifying environmental and social vulnerability: Role of urban Heat Island and air quality, a case study of Camden, NJ. Urban Clim. 2020. [CrossRef]

3. Fahad, M.G.R.; Saiful Islam, A.K.M.; Nazari, R.; Alfi Hasan, M.; Tarekul Islam, G.M.; Bala, S.K. Regional changes of precipitation and temperature over Bangladesh using bias-corrected multi-model ensemble projections considering high-emission pathways. Int. J. Climatol. 2018, 38, 1634-1648. [CrossRef]

4. Fahad, M.G.R.; Nazari, R.; Daraio, J.; Lundberg, D.J. Regional study of future temperature and precipitation changes using Bias corrected multi-model ensemble projections considering high Emission pathways. J. Earth Sci. Clim. Chang. 2017. [CrossRef]

5. Uddin, M.N.; Saiful Islam, A.K.M.; Bala, S.K.; Tarekul Islam, G.M.; Adhikary, S.; Saha, D.; Haque, S.; Fahad, M.G.R.; Akter, R. Mapping of climate vulnerability of the coastal region of Bangladesh using principal component analysis. Appl. Geogr. $2019,102$. [CrossRef] 
6. Fahad, M.G.R.; Nazari, R.; Motamedi, M.H.; Karimi, M.E. Coupled hydrodynamic and geospatial model for assessing resiliency of coastal structures under extreme storm scenarios. Water Resour. Manag. 2020, 34. [CrossRef]

7. Saiful Islam, A.K.M.; Paul, S.; Mohammed, K.; Billah, M.; Fahad, M.G.R.; Hasan, M.A.; Tarekul Islam, G.M.; Bala, S.K. Hydrological response to climate change of the Brahmaputra basin using CMIP5 general circulation model ensemble. J. Water Clim. Chang. 2018, 9. [CrossRef]

8. Fahad, M.G.R.; Nazari, R.; Bhasvar, P.; Jalayer, M.; Karimi, M. A decision-support framework for emergency evacuation planning during extreme storm events. Transp. Res. Part D Transp. Environ. 2019. [CrossRef]

9. Sabrin, S.; Karimi, M.; Nazari, R.; Pratt, J.; Bryk, J. Effects of different urban-vegetation morphology on the canopy-level thermal comfort and the cooling benefits of shade trees: Case-study in Philadelphia. Sustain. Cities Soc. 2021. [CrossRef]

10. Marshall, A. New York City Underwater: Climate Change Mitigation and Adaptation. Student's Thesis, Fordham University, New York, NY, USA, 2016.

11. NYC DEP. Wastewater Treatment System. 2020. Available online: https://www1.nyc.gov/site/dep/water/wastewatertreatment-system.page (accessed on 24 May 2021).

12. Los Angeles Sanitation. Sewers and Pumping Plants. 2020. Available online: https://www.lacitysan.org/san/faces/ home/portal/s-lsh-wwd/s-lsh-wwd-cw/s-lsh-wwd-cw-s;jsessionid=PlKgE34yeAriNfiOADVlUX_T8iGof92MKQnW3VfL0 8kSV-U3QsHv!-1769083674!-253863697?_adf.ctrl-state=4n3w8gtee_1\&_afrLoop=10579647981988962\&_afrWindowMode=0\& _afrWindow (accessed on 24 May 2021).

13. Scawthorn, C.; Flores, P.; Blais, N.; Seligson, H. HAZUS-MH flood loss estimation methodology. II. Damage and loss assessment. Nat. Hazards Rev. 2006, 7. [CrossRef]

14. Federal Reserve Bank of New York. New York City. 2019. Available online: https://www.newyorkfed.org/regional-economy/ profiles/newyorkcity (accessed on 24 May 2021).

15. US Census Bureau. US Census Bureau QuickFacts: United States; US Census Bureau: Suitland, MR, USA, 2020.

16. Allen, T.R.; Crawford, T.; Montz, B.; Whitehead, J.; Lovelace, S.; Hanks, A.D.; Christensen, R.; Kearney, G.D. Linking water infrastructure, public Health and sea level rise: Integrated assessment of flood resilience in coastal cities. Public Work Manag. Policy 2019. [CrossRef]

17. Marsooli, R.; Lin, N. Impacts of climate change on hurricane flood hazards in Jamaica Bay, New York. Clim. Chang. 2020. [CrossRef]

18. Rosenzweig, C.; Major, D.C.; Demong, K.; Stanton, C.; Horton, R.; Stults, M. Managing climate change risks in New York City's water system: Assessment and adaptation planning. Mitig. Adapt. Strateg. Glob. Chang. 2007. [CrossRef]

19. Gornitz, V.; Oppenheimer, M.; Kopp, R.; Horton, R.; Orton, P.; Rosenzweig, C.; Solecki, W.; Patrick, L. Enhancing New York City's resilience to sea level rise and increased coastal flooding. Urban Clim. 2020. [CrossRef]

20. Karamouz, M.; Rasoulnia, E.; Zahmatkesh, Z.; Olyaei, M.A.; Baghvand, A. Uncertainty-based flood resiliency evaluation of wastewater treatment plants. J. Hydroinformatics 2016, 18, 990-1006. [CrossRef]

21. Sajjad, M.; Lin, N.; Chan, J.C.L. Spatial heterogeneities of current and future hurricane flood risk along the US Atlantic and Gulf coasts. Sci. Total Environ. 2020. [CrossRef]

22. Di Nardo, M.; Madonna, M.; Murino, T.; Castagna, F. Modelling a safety management system using system dynamics at the Bhopal incident. Appl. Sci. 2020, 10, 903. [CrossRef]

23. Blake, E.S.; Rappaport, E.N.; Landsea, C.W. The Deadliest, Costliest and Most Intense United States Tropical Cyclones from 1851 to 2006 (and Other Frequently Requested Hurricane Facts); NOAA Technical Report NWS TPC-5; National Weather Service, National Hurricane Center: Miami, FL, USA, 2007.

24. Hatzikyriakou, A.; Lin, N. Simulating storm surge waves for structural vulnerability estimation and flood hazard mapping. Nat. Hazards 2017. [CrossRef]

25. Miccio, A. Impervious Surfaces. Water Watch NYC. 2020. Available online: https://waterwatchnyc.com/tag/impervioussurfaces / (accessed on 24 May 2021).

26. Hamidi, A.; Farnham, D.J.; Khanbilvardi, R.A. Uncertainty analysis of urban sewer system using spatial simulation of radar rainfall fields: New York City case study. Stoch. Environ. Res. Risk Assess. 2018. [CrossRef]

27. Wahl, T.; Jain, S.; Bender, J.; Meyers, S.D.; Luther, M.E. Increasing risk of compound flooding from storm surge and rainfall for major US cities. Nat. Clim. Chang. 2015. [CrossRef]

28. Karamouz, M.; Olyaei, M.; Zarei, L. A Framework for Analyzing Water Quality Reliability of WWTP. In Proceedings of the World Environmental and Water Resources Congress 2017: International Perspectives, History and Heritage, Emerging Technologies and Student Papers, Sacramento, CA, USA, 21-25 May 2017. [CrossRef]

29. De Sousa, M.R.C.; Montalto, F.A.; Spatari, S.M. Using life cycle assessment to evaluate green and grey combined sewer overflow control strategies. J. Ind. Ecol. 2012. [CrossRef]

30. Balci, P.; Cohn, A. NYC Wastewater Resiliency Plan: Climate Risk Assessment and Adaptation. In Proceedings of the International Conference on Sustainable Infrastructure, Long Beach, CA, USA, 6-8 November 2014. [CrossRef]

31. Karamouz, M.; Rasoulnia, E.; Olyai, A.M.; Zahmatkesh, Z. Prioritizing Investments in Improving flood resilience and reliability of wastewater treatment infrastructure. J. Infrastruct. Syst. 2018. [CrossRef]

32. Al-Suhili, R.; Cullen, C.; Khanbilvardi, R. An urban flash flood alert tool for megacities-Application for Manhattan, New York City, USA. Hydrology 2019, 6, 56. [CrossRef] 
33. Kovanen, J.; Oksanen, J.; Sarjakoski, T. Near real-time coastal flood inundation simulation with uncertainty analysis and GPU acceleration in a web environment. Comput. Geosci. 2018. [CrossRef]

34. Jelesnianski, C.P.C.; Chen, J.; Shaffer, J.A. SLOSH: Sea, Lake and Overland Surges from Hurricanes; NOAA Technical Report NWS 48; US Department of Commerce, National Oceanic and Atmospheric Administration, National Weather Service: Silver Spring, MD, USA, 1992.

35. Mayo, T.; Lin, N. The effect of the surface wind field representation in the operational storm surge model of the National Hurricane Center. Atmosphere 2019, 10, 193. [CrossRef]

36. Decker, E.; Dotson-Westphalen, P. Green Space Categorization as a Function of Run off and Infiltration Rates. 2015. Available online: http:/ / www.uvm.edu/ pbierman/classes/morph/morph2003/documents_dnldorview/projects/finalprojects_ withedits/decker_dotson_final.pdf (accessed on 13 July 2021).

37. NYS Department of Environmental Conservation. New York State Stormwater Management Design Manual. January 2015. Available online: https:/ / www.dec.ny.gov/chemical/29072.html (accessed on 24 May 2021).

38. Perica, S.; Martin, D.; Pavlovic, S.; Roy, I.; Laurent, M.S.; Trypaluk, C.; Unruh, D.; Yekta, M.; Bonin, G. Precipitation-Frequency Atlas of the United States; NOAA Atlas 14; US Department of Commerce, National Oceanic and Atmospheric Administration, National Weather Service: Silver Spring, MD, USA, 2013; Volume 9.

39. NOAA. Sea Level Rise Viewer. 2020. Available online: https:/ / coast.noaa.gov/digitalcoast/tools/slr.html (accessed on 24 May 2021).

40. Tokgoz, B.E.; Gheorghe, A.V. Resilience quantification and its application to a residential building subject to hurricane winds. Int. J. Disaster Risk Sci. 2013, 4, 105-114. [CrossRef]

41. Friedland, C.J.; Levitan, M.L. Loss-Consistent Categorization of Hurricane Wind and Storm Surge Damage for Residential Structures. 2009. Available online: https:/ / www.researchgate.net/publication/228513546_Loss-consistent_categorization_of_ hurricane_wind_and_storm_surge_damage_for_residential_structures (accessed on 13 July 2021).

42. FEMA. HAZUS-MH Flood Model; Technical Manual; FEMA: Washington, DC, USA, 2009.

43. Olyaei, M.A.; Karamouz, M.; Farmani, R. Framework for assessing flood reliability and resilience of wastewater treatment plants. J. Environ. Eng. 2018. [CrossRef]

44. Karamouz, M.; Taheri, M.; Khalili, P.; Chen, X. Building infrastructure resilience in coastal flood risk management. J. Water Resour. Plan. Manag. 2019. [CrossRef]

45. Rosenzweig, C.; Solecki, W.D.; Blake, R.; Bowman, M.; Faris, C.; Gornitz, V.; Horton, R.; Jacob, K.; Le Blanc, A.; Leichenko, R.; et al. Developing coastal adaptation to climate change in the New York City infrastructure-shed: Process, approach, tools and strategies. Clim. Chang. 2011. [CrossRef]

46. Serafin, K.A.; Ruggiero, P. Simulating extreme total water levels using a time-dependent, extreme value approach. J. Geophys. Res. Ocean. 2014. [CrossRef]

47. McAllister, T.T. The Performance of Essential Facilities in Superstorm Sandy. In Proceedings of the Structures Congress 2014, Boston, MA, USA, 3-5 April 2014. [CrossRef] 